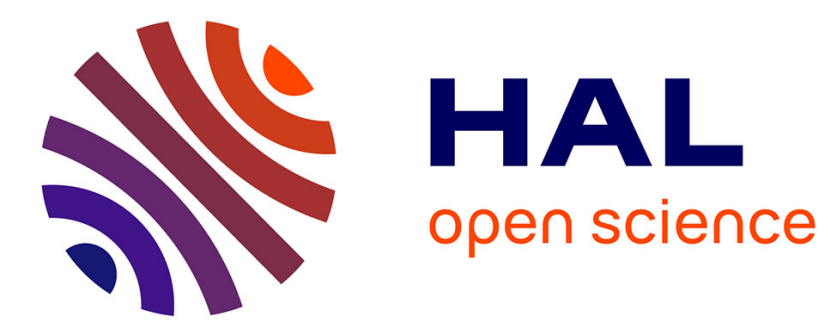

\title{
The Bantu Connective Construction
}

\author{
Mark L.O. van de Velde
}

\section{To cite this version:}

Mark L.O. van de Velde. The Bantu Connective Construction. Anne Carlier and Jean-Chrisophe Verstraete. The Genitive, John Benjamins Publishing Company, pp.217-252, 2013, Case and Grammatical RelationsAcross Languages, ISBN 978902722815 4. hal-00826098

\section{HAL Id: hal-00826098 https://hal.science/hal-00826098}

Submitted on 26 May 2013

HAL is a multi-disciplinary open access archive for the deposit and dissemination of scientific research documents, whether they are published or not. The documents may come from teaching and research institutions in France or abroad, or from public or private research centers.
L'archive ouverte pluridisciplinaire HAL, est destinée au dépôt et à la diffusion de documents scientifiques de niveau recherche, publiés ou non, émanant des établissements d'enseignement et de recherche français ou étrangers, des laboratoires publics ou privés. 


\title{
The Bantu connective construction
}

\author{
Mark Van de Velde (LLACAN - C.N.R.S.)
}

Prefinal version, January 2012. To appear in: Carlier, Anne \& Jean-Christophe Verstraete (eds.) The Genitive. [Case and Grammatical Relations across Languages] Amsterdam: John Benjamins.

\section{Introduction}

When two nominal constituents are in a relation of dependency in the Bantu languages, the syntactically dependent constituent is usually introduced by a relator. In Bantu studies this relator is called connective (also associative, genitive or connexive) element (or pronoun, clitic, prefix, marker or particle). The order is HEAD (R1) - RELATOR (REL) - DEPENDENT (R2). R1 and R2 are short for first and second relatum. Dependency relations are not always unproblematic, as we will see in Section 5.1. The terms relator and relatum are from Dik (1989). I will use the term connective construction to refer to the entire construction, i.e. R1 REL R2, rather than to REL R2, as is sometimes done in the literature. A typical example is provided in (1).

\footnotetext{
${ }^{1}$ Most sources do not provide glosses, so glossing is generally mine. Where glosses are provided in the sources, I adapted them for the sake of homogeneity. I use the Leipzig glossing rules, with the following additions: AG agreement marker, AU augment, CON stem of the connective relator, FV final vowel (a TAM morpheme), GER gerund, HAB habitual, HPST hodiernal past, PF pre-final (a multifunctional TAM-morpheme), POS stem of a possessive pronoun, PPR personal pronoun, R1 first relatum, RP remote past, RPST recent past, SUB subordinator. Arabic numbers gloss overt noun class markers on nouns and roman numbers gloss class/number agreement prefixes.
} 
(1) Kagulu (Tanzania; Petzell 2008: 86)

$\begin{array}{cll}\text { m-eji } & g-a & m u-n y u \\ \text { 6-water } & \text { VI-CON } & \text { 3-salt } \\ \text { R1 } & \text { REL } & \text { R2 }\end{array}$

'salt water'

This paper provides an overview of the variation in connective constructions throughout the Bantu languages. It will be shown that connectives form a category with fuzzy boundaries, for which no definition in terms of necessary and sufficient conditions can be provided. In order to deal with the variation in connective constructions I will adopt an approach inspired by canonical typology, as developed most notably by Corbett (2007). That is, I will define a canonical connective construction and then describe the formal variation found among connective constructions in terms of departures from the canon along several dimensions. Note that a canonical approach makes no claims whatsoever regarding the status of the canonical type as either being frequent or diachronically primary. The canon is simply a starting point for mapping the variation among related constructions. Section 2 introduces the canonical type. Sections 3 to 7 each discuss departures from the canon along a single dimension, viz. departures from the canonical R2 (section 3), from the canonical connective relator (section 4), from the canonical dependency relation (section 5), from the canonical R1 (section 6), and from the canonical arrangement of constituents (section 7).

Depending on how one counts, there are between 300 and 600 Bantu languages, spoken in an area south of a line between Cameroon in the west and Kenya in the east. The internal classification of the Bantu languages is problematic, but by and large the Bantu 
languages can be subdivided in an eastern, a western and a north-western group. The northwestern Bantu languages, spoken in Cameroon, Gabon, Equatorial Guinea, parts of the two Congos and the Central African Republic, are closest to what is generally accepted to be the Bantu homeland. Not surprisingly, linguistic fragmentation is highest in the northwest.

The typological characteristics of the Bantu languages most relevant for this chapter are their noun class system and extensive noun class agreement. Typically, Bantu languages have somewhere between ten and twenty noun classes, which are overtly marked on the noun with a prefix. The noun classes are numbered and usually come in pairs in which the odd numbered class contains the singular nouns and the even numbered class the plurals. Such noun class pairings are traditionally called genders. Nominal modifiers, pronominals and verbs agree in gender with nominal controllers. See Maho (1999) for an overview of Bantu noun classes and agreement.

This study is based on a convenience sample of about fourty areally differentiated Bantu languages. This sample sufficed to find most, if not all, logically possible departures from the canonical type, but it does not allow us to determine how recurrent each of these departures is within the entire family.

\section{The canonical connective construction}

The definition of the canonical connective construction in this section is to serve as a point of reference for an overview of the variation in connective constructions within the Bantu family. The characteristics of the canonical type proposed here are based on knowledge of what is typical in the Bantu languages. In a sense, the canonical connective construction is 
what is the prototypical connective construction, not in the mind of the speaker of a Bantu language, but in the mind of the Bantu linguist.

The canonical connective construction relates nominal constituents headed by a canonical Bantu noun by means of an overt relator. A canonical Bantu noun can be characterised as a lexeme that can function as an argument of a lexical verb and that has a unique gender specification, i.e. that does not derive its gender marking from another element in the context. Canonically there is a uniform element that relates R1 to R2. We will call this element the connective stem and gloss it as $\mathrm{CON}$ (but if a connective relator lacks a stem, i.e. if it consists solely of an agreement marker, the agreement marker that serves as a connective relator will be glossed $\mathrm{CON}$ ). The connective stem canonically takes a prefix (AG) that indexes R1. This prefix belongs to a paradigm called pronominal prefixes in Bantu studies. In Meeussen's (1967) reconstruction of Proto-Bantu grammar the connective stem is reconstructed as - $\sim$ a, where the tilde symbolizes a tone that is harmonic with that of the preceding prefix. I will incorporate this form of the connective stem in the canonical construction (but without the tonal specification). The canonical form of the connective relator is thus AG-a. In the canonical connective construction, the connective relator is placed iconically in between R1 and R2. Since it marks R2 for being syntactically dependent on R1, it is more closely linked to R2 than to R1 and this is reflected in a relatively high degree of morphological bonding between the relator and R2. In all descriptions that I consulted and that discuss this issue explicitly, the degree of bonding between the relator and R2 is higher than that between separate words. Moreover, in the Bantu languages that have pre-head 
modifiers in the NP that I am aware of, the connective relator precedes the first element of R2 and therefore behaves as a phrasal affix. This is shown in the example from Songye in (2).

(2) Songye (DRC; Stappers 1964: 81)

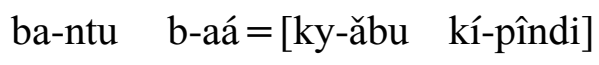

2-people II-CON=VII-their 7-neighbourhood

'the people of their neighbourhood'

Due to the strong phonological integration between the connective relator and the following word, the relator is not analysed as a separate word in Stappers (1964). In many of the languages in my sample, the degree of bonding between REL and R2 can be described as intermediate between that of a word boundary and that of an affix boundary. Therefore, typically, the Bantu connective relator is a proclitic and I will integrate this formal characteristic in the canonical type used in this study.

Semantically, some further characteristics of the canonical construction are that R2 modifies R1 and that the two nominal constituents are not co-referential.

The connective construction is not dedicated to the expression of a specific relation. The examples in (3-8) illustrate equally typical uses of the canonical connective construction. In (3) and (4) the connective construction is used to express linguistic possession. That is, the number of potential referents of R1 is restricted to those that have a privileged relationship with the (prototypically human) individual denoted by R2. 
(3) Kinyamwezi (Tanzania; Maganga and Schadeberg 1992: 89)²

m̀-zuna w-aa-m̀-kı́ma

1-younger_sister I-CON-1-woman

'the younger sister of the woman'

(4) Swahili (Tanzania; Hawkinson 1979: 86)

ni-li-tafuta $\quad$ zawadi $\quad \mathrm{y}-\mathrm{a}=\mathrm{m}$-toto

1SG-PST-seek [9]present IX-CON=1-child

'I sought a present to give to the child' (recipient)

'I sought a present on behalf of the child' (benefit)

'I sought the child's present (i.e. that he misplaced)' (ownership)

R2 frequently qualifies (5-6) or classifies (7) R1, or locates it in space or time (8). Note that the head noun of R2 can be property denoting (5) or entity denoting (6) in a qualifying canonical connective construction.

(5) Mongo (DRC; Hulstaert 1966: 246)

ntando ěy $=$ o-lindó

[9] river IX.CON=3-depth

'a deep river'

\footnotetext{
${ }^{2}$ Maganga and Schadeberg analyse the connective stem as a prefix in Kinyamwezi. However, they point out that the tonal behaviour of the connective relator resembles that of a prefix in some contexts and that of a word in others, which could be used as an argument to analyse the connective relator as a proclitic.
} 
(6) Mongo (Hulstaert 1966: 247)

e-kútu ě-a =n-dosó

7-calabash VII-CON=10-pores

'a porous calabash'

(7) Swahili (Welmers 1963: 433)

nyumba $\quad \mathrm{z}$-a $=$ ma-we

$[10]$ houses $\quad \mathrm{X}-\mathrm{CON}=6$-stones

'houses made of stone'

(8) Mongo (Hulstaert 1966: 255)

m-pótá ě-a =lo-kolo

9-injury $\quad \mathrm{IX}-\mathrm{CON}=11$-foot

'a foot injury'

3. Departures from the canonical $R 2$

This section discusses departures from the canonical R2. The two departures discussed first involve an R2 that has formal characteristics of an adjective (Section 3.1) and a verb (Section 3.2). These departures move gradually from almost canonical connective constructions to typical adjectival and relative constructions respectively. It will be shown that any clear cut- 
off point between connective constructions on the one hand and adjectival and relative constructions on the other hand is arbitrary. Section 3.3 deals with possessive pronouns, which are often connective constructions with a pronominal R2, if not synchronically, then historically. Section 3.4, finally, provides a brief overview of miscellaneous departures in which the R2 position is occupied by members of minor word classes.

\subsection{R2 has adjectival features}

Morphosyntactic departures from the canonical R2 will be increasingly important as we move through this section. In (5) we saw an example of a qualifying canonical connective construction, in which R2 is a canonical noun that denotes a quality. A first departure from this situation is illustrated in (9), where R2 has the morphological properties of a noun, but the distributional potential of an adjective. In contrast to canonical adjectives in Makwe, which "agree in class with the noun on which they syntactically depend" (Devos 2008: 115), the

word kibúúli 'silent' is inherently of class 7 . In contrast to canonical nouns, kibúúli cannot be used as the head of a referential phrase. It occurs only as R2 in a connective construction or as a predicate following a copula. Moreover, it does not have a morphological plural (Maud Devos, p.c.).

(9) Makwe (Mozambique; Devos 2008: 136)

muú-nu $\quad$ w-á= ki-búúli

1 -person $\quad \mathrm{I}-\mathrm{CON}=7$-silent

'a silent person' 
Hulstaert's Mongo grammar (1966: 30-32) distinguishes three types of quality denoting R2s that do not agree in gender. The first type are those that do not agree with R1 at all, they always appear in the singular. This type includes words for 'black', 'white', 'careful' and 'respectful'.

(10) Mongo (Hulstaert 1966: 32)

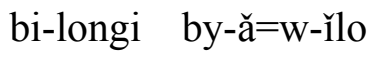

8-faces VIII-CON=3-dark/black_colour

'black faces'

The second and third type illustrate a further departure from the canon, in that the number of R2 depends on that of R1. R2 always agrees in number in the second type (11). Nouns that do not denote a quality, strictly speaking, but rather an entity defined by a quality, are always of the second type (12).

(11) Mongo (Hulstaert 1957: 1176 (a) \& 1966: 30 (b))

a. bo-nto o-ă=li-nsimí

1-person $\quad \mathrm{I}-\mathrm{CON}=5$-taciturn

'a taciturn person' 
b. ba-nto b-ă=ba-nsimí

2-persons II-CON=6-taciturn

'taciturn persons'

(12) a. ba-álí b’ôa-fokú

2-wife II.CON=6-beautiful_women

‘beautiful wives’ (lì-fòkú ‘beautiful woman’ (cl.5))

b. bà-ékòlì $\quad b$-ă = bi-séngà

2-pupil II-CON=8-stupid_persons

‘stupid pupils' (è-séngà 'stupid person' (cl.7))

In the third type, a plural R1 licences, but does not require a plural R2. A plural R2 has a distributive meaning in this case.

(13) Mongo (Hulstaert 1966: 31)

a. nteke $\quad \mathrm{y}-\mathrm{a}=$ bo-salangano

[10]parties $\quad \mathrm{X}-\mathrm{CON}=3$-cheerful

'cheerful parties' (for one person or one occasion)' 
b. nteke $\quad y^{\prime}=\hat{e}-$ salangano

$[10]$ parties $\quad \mathrm{X} . \mathrm{CON}=4$-cheerful

'cheerful parties' (for several occasions)

(14) a. b-ámàtò $\quad b^{\prime}=0$ ô-tsélé

2-women II.CON=3-implacable

'women relentless at quarrel' (in group)

b. b-ámato $b^{\prime}=$ ê-tsélé

2-women II.CON=4-implacable

'women relentless at quarrel' (considered individually)

When R2 also agrees in gender, the resulting construction could be characterised as a connective construction with an adjective in R2 position. R2 is doubly marked for the function of modification: by means of an agreement prefix and by means of the (equally agreeing) connective relator. This type of construction can be found in Koongo of Boko (15).

(15) Koongo of Boko (Congo; Bouka 1994: 14)

a. di-nkondi di-a=di-nené

5-banana $\mathrm{V}-\mathrm{CON}=\mathrm{V}-\mathrm{big}$

'a big banana' 
b. bw-atu bw-a=bu-nené

14-canoe $\quad$ XIV-CON=XIV-big

'a big canoe'

c. m-atu $\mathrm{m}-\mathrm{a}=$ ma-nené

6-canoes VI-CON=VI-big

'big canoes'

In some other varieties of the Koongo dialect cluster the same quality denoting lexemes can be employed in two different constructions with the same meaning, but possibly different pragmatics (Bouka does not provide any information on this). Both construction types involve a connective relator, but in only one of them does $\mathrm{R} 2$ have an agreeing prefix (16a). In the other type of connective construction $\mathrm{R} 2$ is invariant (16b).

(16) Suundi (Congo; Bouka 1994: 16) ${ }^{3}$

a. ki-salu ky-a=kí-kèèke 'a small job'

bi-salu by-a = bí-kèèke 'small jobs'

zi-ngasi z-a = zí-kèèke 'small palm nuts'

\footnotetext{
${ }^{3}$ Bouka (1994) cites Jean Baka (p.c.) as the source of these examples. The tonal difference on the connective relator between the examples in (15a) and (15b) is said to be due to rules of tone displacement. Still according to Bouka, the construction exemplified in (15b) is historically derived from that in (15a) by means of a generalisation of agreement pattern IX in R2 position.
} 
b. ki-salu ky-á=n-kèèke 'a small job'

bi-salu by-á=n-kèèke 'small jobs'

zi-ngasi z-á=n-kèèke 'small palm nuts'

The presence of the connective relator can be optional too. This is the case in Bakueri, also known as Kpe or Mokpwe (17). Since I found no other examples than the one in (17), it is impossible to know whether R2 should be analysed as a class 9 noun or as an agreeing adjective.

(17) Bakueri (Cameroon; Kagaya 1992: 12, 16, 151)

a. mgbá $\quad y-a=$ ndéne

$[9] \operatorname{dog} \quad$ IX-CON=[9]big

'a big dog'

b. mgbâ ndéne

[9]dog IX.big

'a big dog'

In Lingala of Kinshasa the use of the invariant connective relator ya (historically agreement pattern IX) is optional for a closed class of quality denoting lexemes when they modify a noun. These lexemes never agree in gender with the head noun and only four or five of them agree in number. According to Michael Meeuwis (p.c.) the presence versus absence 
of CON marks a subtle pragmatic difference in that the connective relator tends to be used when the head noun is topical (and the qualification new), whereas the absence of CON correlates with a non-topical nominal constituent. Hulstaert (1966: 291) describes a similar distinction for a number of qualifying nouns in Mongo.

(18) Lingala (DRC; Meeuwis 1998: 15; p.c.)

$$
\begin{aligned}
& \text { lo-pángo } \quad(\mathrm{ya}=) \text { mo-ké } \\
& \text { 11-compound } \quad(\mathrm{CON}=) 3 \text {-small } \\
& \text { 'a small compound' }
\end{aligned}
$$

We will come back to connective constructions with a property denoting modifying noun in section 5.1, which discusses dependency reversal.

\section{2. $R 2$ has verbal characteristics}

This section provides a brief overview of connective constructions in which $\mathrm{R} 2$ has verbal characteristics. Thus, it explores the grammatical space in between the canonical connective construction and typical relative constructions. In the simplest case, R2 is a non-finite verb form consisting of a verb stem and a nominal prefix, such as the infinitive, which in many languages has a prefix of class 15 , or the non finite verb form called gerund (gérondif) in Hulstaert (1966), illustrated in example (19). In the canonical case the verb stem denotes an event (19), but often it denotes a property, so that an infinitival R2 can have adjectival 
characteristics (21). Note in passing the difference in coordinating multiple R2s between (19b) and (20). The connective relator is repeated in the latter, not in the former.

(19) Mongo (Hulstaert 1966: 251)

a. i-síni $\quad \mathrm{y}$-ă=n-kǒ kot-a

19-machine $\mathrm{XIX}-\mathrm{CON}=9$-GER $\sim$ write-FV

'writing machine'

b. ba-éfa b-ă=n-kǐ kis-a la m-bétám-á

6-days VI-CON=9-GER $\sim$ sit-FV and 9-lie-FV

'days off' (lit. 'days of sitting and lying down')

c. b-olótsi $\quad$ w-ă=n-dekól-á

3 -goodness III-CON=9-surpass-FV

'really very good' (lit. 'goodness of to surpass')

(20) Ruwund (DRC; Nash 1992: 369)

mà-d ma-kùnd m-à = ku-kùn âp $m$-à = ku-dà?

VI-COP 6-beans VI-CON=15-plant or VI-CON=15-eat

'Are they beans to plant or to eat?' 
(21) Makwe (Devos 2008: 136)

$$
\begin{aligned}
& \text { muú-nu W-á=ku-dóóba } \\
& \text { 1-person I-CON=15-be_lazy } \\
& \text { 'a lazy person' }
\end{aligned}
$$

Bantu infinitives can be expanded in many ways that make them more typically verbal (see Hadermann 1994 for an overview), and all kinds of expanded infinitives can be found in the R2 position of connective constructions. In the following Ruwund examples the infinitive has an object (22) or a subject (23).

(22) Ruwund (Nash 1992: 367)

a. m-es m-à=kù-tekàp ordinateur

6-table VI-CON=15-put computer

'computer table' (lit. 'table of to put computer')

b. mi-jik $\quad y$-à = kù-sangar-esh a-ntu

4-music IV-CON=15-rejoice-CAUS 2-people

'music to make people happy' 
(23) Ruwund (Nash 1992: 370)

$$
\begin{aligned}
& \text { tu-kìmb-in } \quad \text { n-dônd } \quad \text {-à = kù-laal mw-ânt } \\
& \text { 1pl-search-PRS.PROG 9-place IX-CON=15-sleep 1-chief } \\
& \text { 'We are looking for a place for the chief to sleep.' }
\end{aligned}
$$

In (24) the R2 position is occupied by an infinitive that has more verbal properties in that it has passive morphology and is preceded by the negative adverb bílá.

(24) Makwe (Devos 2008: 405)

$$
\begin{aligned}
& \text { ǹ-táama } \quad \text { w-á=bílá } \quad \text { ku-kálángí-iw-a } \\
& \text { 3-sorghum } \quad \text { III-CON=NEG } 15 \text {-fry-PASS-FV } \\
& \text { 'sorghum that has not been fried' }
\end{aligned}
$$

$\mathrm{R} 2$ is more typically verbal (and the resulting construction more typically relative) if it is finite, i.e. when it has a subject prefix. The example in (25) is from Makwe, where the subject prefix is preceded by a connective relator in all non-subject relatives. ${ }^{4}$

\footnotetext{
${ }^{4}$ There is a formal difference between the connective relator when it is followed by a noun (including infinitives) or by a finite verb form: only in the former case does the relator have a structural high tone. Devos (2008:261) suggests that this tonal difference is due to a difference in degree of morphological bonding. In relative verb forms the connective relator is analysed as a (complex) prefix, elsewhere as a proclitic. The morpheme áglossed as I is the third person subject prefix of agreement pattern I.
} 
(25) Makwe (Devos 2008: 394)

vií-nu vy-á=á-yúm-íite

8-thing VIII-CON=I-buy-PRS.PFV.REL

'the things that he has bought'

If the non-subject relative clause has a nominal subject, this follows the verb form in Makwe (26). In Konzo, the nominal subject is in its usual preverbal position, preceded by the connective relator $(27){ }^{5}$

(26) Makwe (Devos 2008: 396)

ku-nyéenje k-a=jí-péele ji-ng'úúnde

17-side XVII-CON=X-grow.PRS.PFV.REL 10-bean

'at the side where the beans grow'

(27) Konzo (Uganda; Tucker 1960: 27)

o-mu-ndú e-y-a=a-ba-ndú bá-lángíra

AU-1-person AU-I-CON=AU-2-people II-saw

'the person whom the people saw'

\footnotetext{
${ }^{5}$ Note that the augment is used in Konzo to pronominalise a connective relator (see section 6.2). The connective relator in Konzo non-subject relative clauses always takes the augment.
} 
The connective relator can also introduce a clause that functions as a complement or an adjunct of a noun and that often cannot be analysed as a relative clause, since the antecedent (R1) does not necessarily have a role in it $(28 \mathrm{a}, \mathrm{b})$. The clause in $\mathrm{R} 2$ position can be complex $(28 \mathrm{c}, \mathrm{d})$. In (28b), the connective relator is followed by an optional subordinating conjunction.

(28) Mongo (Hulstaert $1946(a, b)$ 1966: $278(c, d))$

a. ts-ók-a eqfé é êâ-w-ăné w-ăné to-tá-l-á $\quad$ y-ǒmba

1PL-feel-FV [7]pain VII-CON=3-day 3-day 1PL-COND-eat-FV 19-thing

'We suffer because we haven't eaten anything all day long.'

(lit. 'we feel pain of day day we didn't eat thing')

b. bo-tsó bó-ki w-ílima w-ă=(te) á-ongan-e nkole

3-night III-COP.PST 3-darkness III-CON=(SUB) I-hurt-SBJV [9]injury

'The night was so dark that he hurt himself.'

c. ba-nto bǎ=mpángá ba-kit-áká ko băol-ékel-a ba-móng'ésé

2-people II-CON=next II-arrive-RPST and II.HPST-accustom-FV 2-native '(foreign/European) men who adapt easily to native customs' (literally: 'men of they-have-hardly-arrived-and-they-are-already-accustomed-to-the-natives')

d. bo-támbá w-ă=ngá w-ô-tumb-a bó-fó-longól-é

3-tree III-CON=if 2SG-III-set_fire-FV III-PRS.NEG-burn-FV

'a tree that does not burn if you set fire to it' 
Finally, in a rather idiosyncratic departure from the canon, Mongo has a connective construction in which R2 consists of a fully reduplicated verb stem that characterises R1 in terms of an action that is either repeated or futile.

(29) Mongo (Hulstaert 1966: 256)

a. bo-támbá w-ă=kotá kotá

3-tree $\quad$ III-CON=cut cut

'a tree impossible to cut down'

b. bo-lokó w-ă= sangá sangá

3-speech $\quad$ III-CON=talk talk

'an endless speech'

\section{3. $R 2$ is pronominal}

Possessive pronouns often originate in a connective construction in which $\mathrm{R} 2$ is a pronoun. This origin is fully transparent in some Bantu languages, but has become opaque in many others, to the extent that sometimes a connective origin cannot be demonstrated. A consequence of the connective origin of possive pronouns is that they index both the possessor and the possessed. In other words, they agree with two controllers. The canonical paradigm of possessive pronouns has a form for every possible combination of possessor and possessed. The Namibian Bantu language Herero provides an example of this canonical situation. It has eighteen noun classes, which can each control R1 and/or R2. This produces a 
paradigm of 18 × $22=396$ forms $(22$, since the discourse participants can occur in R2 position too). Examples of possessive pronouns with two non-human controllers are given in (30). The possessive pronouns in this example are glossed as connective constructions (AGCON-AG-PPR). Elsewhere I will gloss them as AG-POS, without making explicit their internal morphological structure.

(30) Herero (Namibia; Möhlig et.al. 2002: 60)

a. òmù-tí n-òví-yàò $\quad$ vy-á- ${ }^{\perp} w-o ́$

3-tree and-8-leaves VIII-CON-III-PPR

'the tree and its leaves'

b. òtjì-kúnìnò n-òmí-tí vy-á-'ty-ó

7-garden and-4-trees IV-CON-VII-PPR

'the garden and its trees'

There are at least three ways in which paradigms of possessive pronouns can depart from regular connective constructions with a pronominal R2. First, the connective relator used in the possessive pronoun can differ from that used in connective constructions with a nominal R2. For instance, in the north-western Mongo dialects the connective stem is $-k a$ when R2 is pronominal and $-a$ elsewhere. Second, frequency of use can lead to a stronger morphological integration of $\mathrm{CON}$ and a pronominal R2, often accompanied by reduction and idiosyncratic phonological changes. Third, in many languages the paradigm of possessive 
pronouns is reduced, often to six stems: two (singular and plural) for each discourse participant and two for the third person, as in the Kagulu paradigm reproduced in table 1 (Petzell 2008: 87).

Table 1: Kagulu possessive pronouns

\begin{tabular}{|l|l|l|l|}
\hline $1 \mathrm{SG}$ & -angu & $1 \mathrm{PL}$ & -etu \\
\hline 2SG & -ako & 2PL & -enu \\
\hline 3SG & -agwe & $3 \mathrm{PL}$ & - ao \\
\hline
\end{tabular}

\subsection{Miscellaneous other departures}

So far we have seen departures from the canonical R2 in the direction of adjectives and verbs, as well as pronominal R2s. It turns out that many other types of elements can occur in R2 position too. What follows is a brief enumeration.

In the majority of Bantu languages, ordinal numbers are introduced by the connective relator (Bynon-Polak 1965: 134).

(31) Eton (Cameroon; Van de Velde 2008: 182)

lèwòl lé ‘báà

|lò-wòl ló=bǎà|

5-hour V.CON=second

'the second hour' 
Another recurrent departure from the canon is with $\mathrm{R} 2$ as a locative noun, derived from another noun by means of a locative prefix. In the following Ruwund examples the class 18 nominal prefix mù- is a locative marker.

(32) Ruwund (Nash 1992: 357)

a. ci-kùmbu c-à = mù-Zaïre

7-house $\quad$ VII-CON=18-Zaire

'Zairian house' (lit. 'house of in Zaire')

b. yi-twaamu y-à= mu-ci-kùmbu

8-chairs VIII-CON=18-7-house

'house chairs' (lit. 'chairs of in the house')

$\mathrm{R} 2$ is an ideophone in (33) and a prepositional phrase in (34-35). Cardinal numbers too are construed as R2 in a connective construction in Bafia (34).

(33) Mongo (Hulstaert 1966: 246)

a. ba-úta b-ă sénjele

6-oil VI-CON ideophone

'pure oil' 
(34) Bafia (Cameroon; Guarisma 2000: 208)

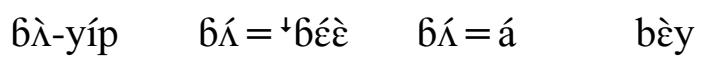

2-women II.CON=two II.CON=LOC [9]past

'the two women of before'

(35) Mongo (Hulstaert 1966: 270)

bo-búngá w-ă=la j-ángo

3-error III-CON=with 5-plan

'an intentional error'

4. Departures from the canonical connective relator

There is considerable variation in the form of the connective relator. Some of this variation is unconditioned, i.e. a number of languages and dialects have a single connective relator that deviates from the canonical Bantu AG- $a$ form. Other languages have several connective relators, the choice of which can be conditioned by factors such as prosody, morphological and/or pragmatic-semantic characteristics of R1 and/or R2, the type of relation between R1 and R2 and/or tense. This section provides an overview, starting with examples of unconditioned variants of AG-a (4.1), followed by some types of conditioned variation (4.24.4). 


\subsection{Unconditioned variants}

In many north-western Bantu languages, such as Eton, Basaa and Bafia, the connective relator has no stem. It consists solely of an agreement marker, which does not necessarily correspond to an agreement prefix used in other modifiers or pronouns. Sometimes the form of this connective relator is similar or identical to a demonstrative, e.g. in Basaa (Hyman 2003: 266).

In languages where the connective relator does have a stem, this is not always -a. Thus, some northern dialects of Mongo have a connective stem ^̌ká rather than $-a$. This variant is found in literary registers in the other dialects, where it also serves in the formation of the possessive pronoun (see section 3, Hulstaert 1965: 171). Another, more frequent, alternative for $-a$ as the only connective stem in Mongo dialects is -na or -nda (Hulstaert 1993: 336). Some languages have an AG-V relator, where the stem is a vowel other than $a$. This is the case for Bodo (D332), where the connective stem is -o (Asangama 1983: 253). Interestingly, the Bodo reflex of the Proto-Bantu comitative relator *na (Meeussen 1967: 115) 'and, with' is no (Asangama 1983: 399). In languages where the stem of the connective relator is a vowel other than $a$, this vowel may be a trace of the pre-prefix or augment of R2 (Nzang Bie 1995: 50-53). The augment is a prefix found in many Bantu languages, whose function differs from language to language. Often it can be characterised as what Greenberg (1978) calls a stage 2 or non-generic article, i.e. a further development of a definite (stage 1) article, in that its use has been generalised to most contexts, excluding generic utterances and inherently definite nominals such as proper names. 
In Kol (Cameroon), we find a peculiar departure from the canonical AG- in the connective relator. One of the three different series of connective relators, the so-called "qualificative associative", has the canonical connective stem -a (Henson 2007: 114), but this stem is preceded by a paradigm of agreement prefixes that usually appears before consonant initial stems, which may point to a $-\mathrm{Ca}$ (possibly $-n a)$ origin of the stem.

\section{2. "Amplexives"}

A well known example (Welmers 1963, Güldemann 1999) of conditioned variation in the form of the connective relator is that in which the AG-a connective is followed or replaced by a so-called amplexive morpheme, often $k a$ or $k w a$ (but many other forms can be found throughout Bantu), when R2 belongs to class 1a. ${ }^{6}$ Class 1a usually contains proper names, kinship terms, borrowings and some other nouns. These nouns lack a class prefix and/or an augment and trigger class 1 agreement. Usually class $1 \mathrm{a}$ is analysed as a subclass of class 1 , but see Van de Velde (2006) for an alternative analysis that argues that these nouns lack a gender specification.

In Zulu, for instance, the amplexive $k a$ replaces the connective stem $a$. Moreover, it is preceded by the subject agreement prefix, rather than by the so-called pronominal prefix. According to Doke (1997: 120), the ka-relator appears before class 1a nouns, obligatorily

\footnotetext{
6 The exact conditioning for the appearance of the "amplexive" may be more intricate than that in many languages, e.g. involving only proper names or only class 1a nouns with human reference, or proper names whether they belong to class 1a or not. Better descriptive work is needed on this issue.
} 
when they have animate reference (37), optionally when they do not (38). Example (36) illustrates the default connective relator before an animate R2 that does not belong to class $1 \mathrm{a}$.

(36) Zulu (South Africa; Doke 1997: 120)

i-zi-hlalo $\quad$ z-o $=$ m-lungu

AU-10-chairs X-CON.1.AU=1-white_man

'the white man's chairs'

(37) i-zi-hlalo

$\mathrm{zi}-\mathrm{ka}=\mathrm{baba}$

10.AU-10-chairs $\mathrm{X}-\mathrm{CON}=$ father

'father's chairs'

(38) a. u-bu-khulu bu-ka=tamatisi

14.AU-14-size $\mathrm{XIV}-\mathrm{CON}=$ tomato

'the size of the tomato'

b. u-bu-khulu bo = tamatisi

14.AU-14-size XIV.CON=tomato

'the size of the tomato' 
Apparently, animacy is not the only relevant factor for the obligatory use of the $k a$ connective, since Doke points out that names of coins, such as umpondwe, usheleni, umfagolweni and uzuka "take only the construction with -ka." This may mean that the kaconnective is obligatory if $\mathrm{R} 2$ is a class 1a proper name (or kinship term) and that names for different types of coins are construed as proper names in this construction. Several hypotheses concerning the origin of $k a$ have been forwarded: a contraction of the connective relator $k w a$, which contains the locative class 17 agreement prefix $\mathrm{ku}$ - (Van Eeden 1956), a reflex of a proto-Niger-Congo connective stem ${ }^{*} k a$ (Welmers 1963), a reflex of the often diminutive class 12 prefix $\mathrm{ka}$-, a grammaticalisation of the Proto-Bantu noun *ka 'wife' (Bosch 1997), and finally an origin in a Southern Bantu locative prefix ka- (Güldemann 1999).

Specific connective relators for an R2 belonging to class 1a do not always involve an amplexive morpheme. In Oshindonga the connective relator is AG- $a$ before a class 1a noun and AG elsewhere (Fivaz 1986: 85). ${ }^{7}$

\subsection{Different relators for different relations}

\footnotetext{
${ }^{7}$ It may be that the presence versus absence of an augment is the real conditioning factor here, rather than class 1a membership. Class 1a nouns typically lack an augment and since the augment is vocalic in Oshindonga, the absence of the connective stem -a before other nouns might be due to a phonological rule of vowel hiatus resolution. Since Fivaz does not explicitly mention the connective construction in his overview of where vowel hiatus resolution rules apply, we can assume that he analyses the connective relator as lacking a stem except before class 1a nouns. An example of a connective construction with an R2 of class 8 could show which analysis is correct, since the augment of class 8 is $i$ - and vowel hiatus resolution in the case of $a+i$ involves coalescence to $e$. Unfortunately, there is no such example in his grammar.
} 
The choice between multiple connective relators can be conditioned by the function of the modifier, i.e. whether CON R2 classifies, qualifies, quantifies or anchors R1. Thus, the northwestern Bantu language Kol has three paradigms of connective relators (Henson 2007: 113). The connective relator that Henson calls basic consists of AG ( ${ }^{H}$ in class $3, \varnothing$ in classes 1,9 and 10). The connective relator called possessive consists of the stem mò, preceded by a floating high tone in classes 2-8. Finally, there is a nearly canonical AG-a relator (see 4.1) called qualificative. Henson's description does not make clear how these connectives differ from each other functionally, and the descriptive labels are not very revealing of their function. Nevertheless, it seems clear that the choice for one of the three types of connective construction in Kol depends on the nature of the relation expressed by the connective.

There are several cases in which a non-canonical relator is used to mark a (type of) possessive relation, as defined in section 2 , where a canonical relator is used for any other relation. For instance, several Mongo dialects have more than one connective stem, usually $-a$ and another one, viz. -ná, -ká, -áká, -náká, -ánáká or ־lěka. In these variants the -a connective tends to be the more general one, whereas the other stem usually expresses possession or some kind of focus on R2 (Hulstaert 1993). The exact functional difference between the two connective relators is not always clear. The following examples (39-40) are from the Bombwanja dialect (Hulstaert 1965: 172). 
(39)

m-póngo y-á=n-sombo

9-fat $\quad$ IX-CON=9-pig

'pork fat'

(40) m-póngo i-ná n-sombo

9-fat IX-CON 9-pig

'the fat of the pig'

The connective relator ־lěka historically derives from a relative form of the copula le 'be' followed by the preposition ěka 'at (somebody's place), ${ }^{8}$ It is used to express ownership (and contrastive focus on the owner). Consequently, R2 must have human reference.

(41) Mongo (Hulstaert 1965: 178)

a. w-áto bǒ-lěka Mbangó

3-canoe III-CON Mbango

'Mbango's canoe (not sb. else's)'

b. bi-tóo bǐ-lěka wě

8-clothes VIII-CON 2SG

'your own clothes'

\footnotetext{
${ }^{8}$ According to Hulstaert (1965:178) native speakers are not aware of this origin, i.e. they do not recognise the preposition 'at (somebody's place)' as a constituting part of the connective relator.
} 
In Makwe, if R2 is human and singular, i.e. if it is a prototypical possessor, the connective relator takes the form of a possessive pronoun (42a). The canonical connective relator cannot be used $(42 \mathrm{~b}){ }^{9}$

(42) Makwe (Devos 2008: 136)

a. ki-táabu c-áke=mw-áana

7-book VII-I.POS $=1$-child

'The book of the child.'

b. *ki-táabu c-á=mw-áana

7-book VII-CON $=1$-child

There is prosodic evidence for the claim that the possessive pronoun functions as a relator in this construction. Devos (2008: 136) points out that "[w]hereas the possessive [pronoun] normally occurs in a single phonological phrase with the possessed it now occurs in a single phonological phrase with the possessor, the possessed forming a phonological phrase on its own." The possessive pronoun can also have a specific tone pattern and some phonological reduction in the construction exemplified in (42a). Compare (42a) to (43). In (43) the

\footnotetext{
${ }^{9}$ Interestingly, the canonical connective construction is used (obligatorily) if a singular, human R2 is itself modified by a possessive pronoun: ki-táabu c-á=mw-áná w-áa-ngu (7-book VII-CON=1-child I-CON-1SG.POS) 'the book of my child'.
} 
possessive pronoun has phrase final penultimate lengthening, not R1. In (42a) it is the other way around.

(43) ki-tabú cáa-ke (mw-áana) 'his/her book, (the child’s)'

Similar constructions can be found in other Bantu languages (46-47), where the exact conditioning for its use may differ. Petzell (2008) does not discuss the Kagulu construction in example (44), which I found in a text, but note that R2 is human and singular, which may mean that Kagulu is similar to Makwe in this respect. In Ruwund R2 does not need to be singular and the use of a possessive pronoun relator is optional (45).

(44) Kagulu (Petzell, 2008: 197)

di-sina dy-akwe mw-ana-angu

5-name V-3SG.POS 1-child-1SG.POS

'My child's name'

(45) Ruwund (Nash 1992: 364)

ci-kùmbu c-èndaay-Yâav / ci-kùmbu c-a-Yâav

7-house VII-3SG.POS-Yaav / 7-house VII-CON-Yaav

'Yaav's house'

4.4. Tense 
In a number of Bantu languages, such as Tetela and Mongo, the connective construction has a past versus non-past tense distinction. In order to express that the (usually possessive) relation does no longer hold or that the relation between $\mathrm{R} 1$ and $\mathrm{R} 2$ is due to a past event, these languages use a relative past tense form of the copula as a connective relator (46). In this construction, the copula replaces the canonical connective relator, which is the main argument for analysing it as a connective relator. Note in this respect that REL=R2 can follow a copula as a non-verbal predicate in Mongo, see example (78a) in Section 6.2.

(46) Mongo (Hulstaert 1966: 145)

a. li-sála lǐ-kí ngóya

5-field V-CON.PST my_mother

'the field that my mother planted'

b. ts-ă tǒ-kí 'mí

13-fire XIII-CON.PST 1SG

'the fire I lighted'

In their typological overview of nominal tense, Nordlinger and Sadler (2004: 781) point out that in constructions like the Bantu connective construction there are two semantic predicates with respect to which the tense marker may be interpreted: "One possibility is that the tense marker temporally locates the nominal referent itself (e.g. 'former house'). Another possibility is that the tense marker does not refer to the nominal, but rather provides the time at which the possessive relation holds (e.g. 'formerly possessed')." The interpretation of 
nominal tense in such constructions is ambiguous in the majority of the languages of their sample (which does not include Bantu languages). I do not have sufficient data for an analysis of the preferred interpretation of tense in Bantu connective constructions. The examples I found contain no clear illustrations of a cancelled possession interpretation. In contrast, examples (46a) and (46b) illustrate a third possible interpretation, viz. a temporal location of the establishment of the possessive relation.

\section{Departures from the canonical dependency relations}

\subsection{Dependency reversal: $R 1$ is the attribute}

Several Bantu languages show examples of so-called dependency reversal in connective constructions, in that the morphosyntactic head (i.e. R1) modifies the morphosyntactic dependent (R2), as illustrated in the Eton examples in (60-61). Similar constructions have been identified in languages as diverse as Basque, Hausa, Latin and some Oceanic languages of northwest Melanesia (see, e.g., Malchukov 2000, Ross 1998). Within Bantu, this construction type is common only in the north-west. A short survey suggests that dependency reversal is an areal phenomenon that can be found in the core of the so-called Macro Sudan belt, comprising Nilo-Saharan, Niger-Congo and Afroasiatic languages (see Güldemann 2008). More research is needed to confirm this. 
(47) Eton (Van de Velde 2008: 218)

ì-ngúngwál í=m-ôd

7-miserable VII.CON=1-person

'a miserable person'

(48) ̀̀-púm ndá

3-white III.CON.[9]house

'a white house'

R1 determines external agreement (49a), at least when agreement is syntactic. In languages that have semantic agreement, agreement will be determined by R2. In Eton, semantic agreement occurs on pronominal targets when the controller is a noun with human denotation (including personified animal characters in fairy tales), that does not belong to gender $1 / 2(49 b)$.

(49) Eton (Van de Velde 2008: 402)

a. dô mìn-kód mí=mbú mí-`bá mí-ngá-só

then 4-skinny IV.CON=[10]dog IV-two IV-RP-come

'Then two skinny dogs came.' 
b. bó è̀̀y bó nâ: [“íní yô byàkê.”]

\section{II.SUBST with II.SUBST CMP}

'They (the dogs) said to them (the animals): ["This one (road) we will go.’]'

Languages in which the same property noun can be construed either as R2 or as R1 may provide insight in the way dependency reversal originated. In Mongo dependency reversal is rather rare. When it occurs, the property denoting noun acquires an augmentative reading, as seen in the examples in (50) from Hulstaert (1966: 247). Rodegem (1970) proposes a similar analysis for some property nouns in Kirundi.

a. e-sus' é-a $=$ nsombo

7-bigness VII-CON=[9]wild_boar

'a huge boar'

b. n-sombo ě' = e-susá

9-wild_boar IX.CON=7-bigness

'a big boar'

Some Mongo nouns expressing superlative qualities can only appear in R1 position in connective constructions, e.g., ekóla 'tremendous, splendid' in (51). 


$$
\begin{aligned}
& \text { (51) e-kóla e è-a }=\mathrm{i}-\mathrm{l} \mathrm{mb} \varepsilon \\
& \text { 7-tremendous VII-CON=5-house } \\
& \text { 'a tremendous house' }
\end{aligned}
$$

Note that the dependency reversal constructions discussed here should be distinguished from binominal constructions in which R1 and R2 both refer to objects (rather than properties), such as in English this crook of a servant. This type is more common in the languages of the world and can be found throughout the Bantu family, not only in the northwest. It departs from the canonical dependency relations too, in that R1 and R2 are coreferential (see Section 5.2). It is very frequently used to express 'male' (R1 = 'husband'), 'female' (R1 = 'wife') or 'small/young' (R1 = 'child') (52).

(52) Eton (Van de Velde 2008: 220)

j̀̀-jóm mbú

3-husband III.CON.[9]dog

'male dog'

\section{2. $R 1$ and $R 2$ are coreferential}

Another set of connective constructions depart from the canonical construction in that R1 and R2 are coreferential. Modification in these constructions is either restrictive or non-restrictive, depending on the type of relata, the position of the more general term with respect to the more 
specific one, and the presence or absence of a connective relator. In this section, I have to rely heavily on examples found in Hulstaert's description of Mongo.

5.2.1. Non-restrictive modification. When $\mathrm{R} 2$ is a proper name for an individual of the category expressed by R1, the connective construction expresses the relation of 'being called'. This can be compared to prepositional constructions like the city of London and the month of August in English. As in English, the construction is used with some types of proper names (e.g., place names), not with others (e.g., personal names), where mere juxtaposition is used (see below, section 5.2.2.).

(53) Mongo (Hulstaert 1966: 250)

a. $\quad$ i-bonga $\quad$-ă= Mbándáká

5-town $\quad \mathrm{V}-\mathrm{CON}=$ Mbandaka

'the town of Mbandaka'

b. $\quad$ batswá b' = Îkéja

2-pygmee II.CON=Ikeja

'Ikeja pygmies'

In languages like English, the possibility of occurring as the second member in a close appositional construction of the type the city of London can be used as a formal criterion for proper name status (Van Langendonck 2007: 87). In at least some Bantu languages this 
criterion is not valid, since we find examples of connective constructions very similar to those in (53), in which R2 can hardly be analysed as a proper name.

(54) Orungu (Gabon; Odette Ambouroue, p.c. $)^{10}$

a. òywángà $\quad$ w = ókwárà

3.iron.tool.DEF III.CON=3.machete.INDF

'the iron tool called/of the type machete'

b. nyámà $\quad \mathrm{y}=$ ínyárè

9.animal.DEF IX.CON=9.cow.INDF

'the animal called/of the type cow'

(55) Mongo (Hulstaert 1966: 250)

li-kongá j-ă=bo-ntómbá

5-lance V-CON=3-type.of.lance

'a lance of the type bontomba'

I have no examples of such constructions in context and therefore do not know how they should be interpreted. They may be equivalent to the Eton construction illustrated in (56-58), where the function of the semantically redundant more general term is reminiscent of noun classifiers in some Australian languages (see Rijkhoff 2002: 74). They do differ formally, in

\footnotetext{
${ }^{10}$ It is very unusual for Bantu languages to have a formal distinction between definite and indefinite nominals. See Ambouroue (2007) for a description.
} 
that the more general term occupies R2 position in Eton (Van de Velde 2008: 222), whereas $\mathrm{R} 2$ is occupied by the more specific term in the Orungu and Mongo examples (54-55).

(56) غ̀-yán

$$
\varepsilon={ }^{\downarrow} \text { nóy }
$$

5-green_mamba V.CON=[9]snake

'green mamba'

(57)

bé-'té wô yòlò mé-'bádná mé=mwé

II-PR 2SG.PPR INF-give LT.6-nickname VI.CON=6-name

'They give you a nickname.'

(58) ì-sòm 1=m-úná

7-toddler VII.CON=1-child

'a toddler'

Modification is necessarily non-restrictive when R1 is pronominal, especially with first and second person pronouns. The presence of a connective relator is optional in such appositive constructions with a pronominal R1. According to Hulstaert (1966: 290) the presence of a connective relator highlights the relevance of the modification. 
(59) Mongo (Hulstaert 1966: 242)

a. emí ǒ-a=bo-laki

$$
\text { I } \quad \mathrm{I}-\mathrm{CON}=1 \text {-instructor }
$$

'I, the instructor'

b. ísó $b-a ̆=t u u$

we $\quad$ II-CON=black

'we, blacks'

5.2.2. Restrictive modification. In Mongo, contrary to English, the order in the appositional construction involving a place name illustrated in (67) can be reversed. The resulting construction is used to restrictively modify the place name in R1 position, for instance to distinguish places of different categories that bear the same name (60). Another type of restrictive modification of a place name can be seen in (61), where the village name Batsina has a fully transparent etymology in the plural noun batsína 'origins'. The connective construction with the basic level term 'village' in R2 position is used to disambiguate between the village name and its etymology. Note that, strictly speaking, R1 is not construed as a proper name in (60-61), but rather as a deproprial noun, i.e. a noun meaning 'individual called $x$ '. See Van de Velde and Ambouroue (2011) for a discussion of the distinction between proper names and deproprial nouns in the Bantu language Orungu. 
(60) Mongo (Hulstaert 1966: 250)

Mbándáká ěa = i-bonga

Mbandaka IX-CON=5-town

'Mbandaka the town (not the indigenous village)'

(61) Mongo (Hulstaert 1966: 251)

Batsína $b^{\prime}=$ ǒ-moto

Batsina VI.CON=3-village

'Batsina the village'

In another set of Mongo constructions, the presence of a connective relator signals restrictive modification, whereas non-restrictive modification is signaled by means of mere juxtaposition. The function of $\mathrm{R} 2$ in the connective construction is to disambiguate between two or more possible referents of R1.

(62) Mongo (Hulstaert 1966: 289)

a. nkàngà Ìkányà

[9]fetishist Ikanya

'the fetishist Ikanya'

b. ì-kányà $\quad \mathrm{y}$-ă=nkàngà

19-Ikanya XIX-CON=[9]fetishist 
'Ikanya the fetishist (not another person called Ikanya)'

(63) Mongo (Hulstaert 1966: 289)

a. ndòí ě-káḿ bò-làkì

[9]friend IX-my 1-instructor

'my friend, the instructor'

b. ndòí ě-káḿ ě-à= bò-làkì

[9]friend IX-my IX-CON=1-instructor

'my friend, the instructor (not another friend).'

Interestingly, Mongo has another means of distinguishing between a restrictive, disambiguating and a non-restrictive reading in connective constructions of the type discussed here. In (64) agreement marks the difference between the two readings. In (64b) the use of agreement pattern I signals that the agreement controller is not in need of referential disambiguation (see Van de Velde 2006). Therefore, it is non-restrictively modified by CON R2. It is not clear whether the use of alternative agreement patterns described here is restricted to personal proper names in R1 position.

(64) Mongo (Hulstaert 1966: 7)

a. Ilumbé $\quad y$-ă=bo-kúnji

[19]Ilumbe XIX-CON=1-harpist

'Ilumbe the harp player (not another person called Ilumbe)' 
b. Ilumbé ǒ-a=bo-kúnji

Ilumbe $\quad \mathrm{I}-\mathrm{CON}=1$-harpist

'Ilumbe the harp player'

5.2.4. $\mathrm{X}_{1}$ CON $\mathrm{X}_{1}$ 'a real $X$ '. In the extreme case $\mathrm{R} 1$ and $\mathrm{R} 2$ are identical, rather than merely co-referential. The non-compositional meaning of the construction is 'a real $x$ '. I found examples in Mongo and Kinyarwanda.

(65) Mongo (Hulstaert 1966: 257)

a. nsósó ěa = nsósó

$[9]$ chicken IX-CON $=[9]$ chicken

'a real chicken (not a similar bird)'

b. t-o-n-jél-ák-é bo-sáánga w’ồ-sáánga,

PROH-2SG-1SG-bring-PF-SBJV 3-spiral_ginger III.CON=3-spiral_ginger

o-n-jêl-ak-a bo-sáánga $\quad$ w’ = ě-sukúlu

2sG-1SG-bring-PF-IMP 3-spiral_ginger III.CON=7-owl(sp.)

'Don't bring me a Costus afer (spiral ginger) proper, bring me one of the esukulu variety. $^{11}$

\footnotetext{
${ }^{11}$ Esukulu is a species of owl (Ciccaba woodfordi Smith), whose cry is seen as a bad omen. In Costus afer and other plants it refers to a type of malformation which the Mongo attribute to the fact that the plant was planted too late in the evening, after the owl's cry (Hulstaert 1957: 606).
} 
(66) Kinyarwanda (Rwanda; Kimenyi 1989: 54)

umugore nya mugore 'a real wife'

umugabo nya umugabo 'a real man'

umuntu nya muntu ' a real person'

The Kinyarwanda examples show a number of peculiarities not discussed by Kimenyi. First, nya is analysed as a connective relator by Kimenyi, but it is not the connective form of class 1 (which is $w a$ ). Second, in two of the three examples the augment of R2 is dropped and third, all examples are with human nouns, which may or may not be a coincidence.

In a rather extreme departure from the canon, Makwe has a connective construction with two identical infinitival relata. I have no data regarding this construction other than the example in (67).

(67) Makwe (Devos 2008: 136)

mámáá-ye kú-m-móona kw-á=kú-m-móona ku-fúláái

[9]mother-3SG.POS 15-I-see XV-CON=15-I-see 15-be_happy

'His mother became happy the very minute she saw him.' 


\subsection{The connective construction has a non-compositional meaning}

The meaning of the canonical connective construction can normally be derived from the meaning of its constituents, R1 and R2. Semantically opaque connectives abound in the Bantu languages, however. The meaning of the entire construction can be partly (68a) or fully (68b) opaque.

(68) Eton (personal field data)

a. ì-só í-bégî

|ì-só $\quad{ }^{\mathrm{H}}=\mathrm{ì-b}$ gìi $\mid$

7-plate VII.CON=7-tear

'breakable/porcelain plate (as opposed to the traditional wooden plate)'

b. kpèkpàg à=njì

toothbrush $\quad$ I.CON=gorilla

'first glass of palm wine in the morning'

Names of biological species, especially those low on the (folk) taxonomy, are often partly opaque connective constructions (69). 
(69) Mongo (Hulstaert 1966: 250)

e-káá ěa = bo-ntamba

7-anabas VII-CON=1-slave

'mottled ctenopoma, Anabas oxyrhynchus (fish species)' (lit. 'Anabas of slave')

Sometimes, a non-compositional meaning is formally signalled. In Mongo, for instance, idiomatic connective constructions can have a relator that consists solely of the stem a, i.e. without AG (Hulstaert 1965: 173).

a. ba-tói $b$-ă $=n j \jmath k u$

6-ears VI-CON=[9]elephant

'the ears of the elephant'

b. ba-tói ’ ă $=$ njoku

6-ears $\mathrm{CON}=[9]$ elephant

'mushrooms with large caps (probably a species)'

In Makwe, some semantically opaque connective constructions have a tone bridge between the first high tone of R1 and the last one of R2 (Devos 2008: 112), which points to their univerbation, since tone bridge formation is a rule that applies within the lexical domain in Makwe. However, these compounds retain morphological characteristics of full syntagms, in that the connective relator agrees in number with $\mathrm{R} 1$. 
(71) Makwe (Devos 2008: 112)

a. li-kójóojo (class 5) 'sea cucumber’; luú-zi (class 11) ‘thread'

b. li-kójójó-ly-á-lúú-zi

5-sea_cucumber-V-CON-11-thread

'sea cucumber (sp.)'

c. ma-kójójó-y-á-lúú-zi

6-sea_cucumber-VI-CON-11-thread

'sea cucumbers (sp.)'

(72) ǹ-kóngá-w-á-n-néembo

3-trunk-III-CON-1-elephant

'banana (sp.)'

Other semantically opaque connective constructions in Makwe have an irregular tone pattern or contain words that do not exist in isolation.

\section{Departures from the canonical RI}

The connective relator marks $\mathrm{R} 2$ for the function of modification and it is prosodically and morphosyntactically closely linked to R2. In contrast, R1 is much less affected by the 
connective construction. Therefore, departures from the canonical R1 are less relevant for this overview and I will pay less attention to them. Section 6.1 provides a brief and incomplete enumeration of constructions in which $\mathrm{R} 1$ is not a canonical noun. The most relevant departure from the canon is that in which there is no R1, i.e. in which CON R2 is used independently, discussed in section 6.2.

\subsection{R1 is not a canonical noun}

In $\mathrm{R} 1$ position we find more or less the same range of variation as in $\mathrm{R} 2$ position: infinitives, ideophones, pronominals, numbers, and so on. An infinitive R1 is illustrated in (73-74). The connective relator can introduce a diverse set of verbal complements and adjuncts, such as adverbials (73) and agents/notional subjects (74).

(73) Kete (DRC; Kamba Muzenga 1980: 187)

kù-cìmb kù-a = mánkâm

15-walk XV-CON=nothing

'a pointless walk'

(74) Shona (Zimbabwe; Perez 1985: 120)

kù-chémà kw-é= mw-àná

17-cry XVII-CON=1-child

'the crying of the child' 
In Mongo, when a gerund is followed by its object, the latter is introduced by a connective relator if and only if the gerund heads a constituent that functions as a clausal subject. In all other cases the object follows the gerund without extra marking. Hulstaert's interpretation of this is that the gerund is more nominal in character when in subject position and more verbal in other positions.

(75) Mongo (Hulstaert 1966: 294)

a. n-ká kúnd-a ě-a = b-óna [éfosóngi la wě]

9-GER beat-GER IX-CON=1-child

'Beating the child [doesn't suit you].'

b. n-ganja ě-a=n-ká kúnd-a b-óna

9-stick IX-CON=9-GER beat-GER 1 -child

'a stick for beating a child'

When $\mathrm{R} 1$ is a locative noun derived from a non-locative noun by means of one of the locative class prefixes, many Bantu languages allow alternative agreement patterns. That is, the connective relator can agree with the inherent noun class of R1 (76a, 77a) or with the locative class (76b, 77b). 
(76) Ruwund (Nash 1992: 357)

a. ku-ci-kùmbu c-à=Yâav

17-7-house $\quad$ VII-CON=Yaav

'at Yaav's house'

b. ku-ci-kùmbu kw-à= Yâav

17-7-house $\quad$ XVII-CON=Yaav

'at Yaav's house'

(77) Makwe (Devos 2008: 135)

a. pa-li-pááta ly-á=n-náandi

16-5-stump V-CON=3-tree

'at the stump of the tree'

b. ǹ-nyúumba mw-á=íimba

18-[9]house XVIII-CON=[1a]lion

'in the house of the lion'

\subsection{R1 is absent}

In many Bantu languages the connective relator can be used pronominally. It then either agrees endo- or exophorically, or it selects a default agreement pattern. Agreement on the pronominalised connective relator is anaphoric in the Mongo examples in (78) and exophoric with an intended class 5 controller in the Ruwund example (79a). The connective relator acts 
as an independent pronoun in (79b), where it selects agreement pattern VII, the default pattern for the singular in Ruwund (the plural is VIII). ${ }^{12}$

(78) Mongo (Hulstaert 1966: 240)

a. b-ón’ o-né á-fa ǒ-a = bo-laki

1-child I-this I-COP.PRS.NEG I-CON=1-instructor

'This child is not that of the instructor.'

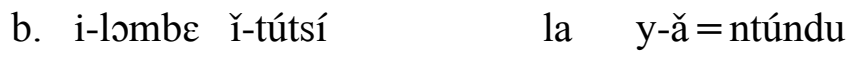

19-house XIX.REL-be_close with XIX-CON=[9]edge

'the house that is close to that at the edge'

c. by-ili ngá by'=ô-senge

4-roots like IV.CON=3-uapaca

'roots like those of an Uapaca guineensis'

(79) Ruwund (Nash 1992: 359)

a. Ni-kàt-in d-à = Yâav

1SG-like-PRS.PROG V-CON=Yaav

'I like Yaav's' (referring to a class 5 controller)

\footnotetext{
${ }^{12}$ In Nash's (1992:359) words "Without specific contextual referents, cl 7 and cl 8 associative phrases refer automatically to implicit côm 'thing' and yôm 'things' respectively."
} 
b. Tù-kwet-àp $\quad$ c-à = kù-mw-ink

1PL.NEG-have-NEG VII-CON=15-I-give

'We don't have anything to give him/her.' (lit. 'We don't have of to give him.')

In such languages there can be a difference between coordinated R2s and coordinated $\mathrm{REL}=\mathrm{R} 2 \mathrm{~s}$, such that coordinated R2s together modify one R1 (80a), whereas coordinated $\mathrm{REL}=\mathrm{R} 2 \mathrm{~s}$ involve different referents $(80 \mathrm{~b})$.

(80) Mongo (Hulstaert 1966: 286)

a. i-lombe $\quad \mathrm{y}$-ă=Boliá la Bolínga

19-house $\mathrm{XIX}-\mathrm{CON}=$ Bolia and Bolinga

'the house of Bolia and Bolinga'

b. i-lombe $\quad y$-ă=Boliá $\quad$ la $\quad y$-ă = Bolínga

19-house $\mathrm{XIX}-\mathrm{CON}=$ Bolia and $\mathrm{XIX}-\mathrm{CON}=$ Bolinga

'the house of Bolia and that of Bolinga'

If a pronominalised connective construction modifies a constituent that is itself R2 in a connective construction, the result is a succession of two connective relators (81b). 
(81) Tswana (Botswana; Creissels 1993: 349)

a. ̀̀-hínánà $\quad$ w-á=sì-lépè $\quad$ s-á=mò-ńná

3-handle III-CON=7-axe VII-CON=1-man

'the handle of the axe of the man'

b. ̀̀-hínánà $w$-á=s-á=mò-ńná

3-handle III-CON=VII-CON=1-man

'the handle of the one of the man'

We saw in section 3.2 that the subject prefix is preceded by a connective relator in all non-subject relatives in Makwe. The antecedent of the relative clause occupies the R1 position. A headless relative clause can be formed by leaving out R1. Note that the resumptive demonstrative pronoun kuuyá is optional in (82) (Maud Devos, p.c.).

(82) Makwe (Devos 2008: 394)

ǹ-ní-úuma k-a = ni-li-piy-íite kuu-yá

1SG-PRS.PFV-come_out 17-CON=1SG-REFL-hide-PRS.PFV.REL 17-DEM

'I came out from where I was hiding.'

In languages that have an augment, this often functions as a pronominaliser when prefixed to modifiers such as the connective relator (83b). 
(83) Kete (Kamba Muzenga 1980: 111, 113)

a. o-mw-a:n $\quad$ y-a:=kú-m-pal

1.AU-1-child $\quad \mathrm{I}-\mathrm{CON}=17-9$-face

'the first child'

b. ó-y-a: =kú-m-pal

I.AU-I-CON=17-9-face

'the first one'

(84) Bemba (Zambia/DRC; Tsibashu Balekelay 1985: 34)

a. u-mw-ana $\mathrm{w}$-a = ma-somo

1.AU-1-child I-CON=6-school

'the child from school'

b. ù-w-ă=ma-somo

I.AU-I-CON=6-school

'the one from school'

(85) Dzamba (DRC; Bokamba 1971: 224)

o-Salomi tecneki o-mw-ana $\quad \mathrm{w}-\mathrm{a}=\mathrm{m}$-bongo emba, kasi o-w-a = n-gbeya

1.AU-Sally did_not_see 1.AU-1-child I-CON $=9$-elephant $\quad$ NEG $\quad$ but I.AU-I-CON $=9$-pig

'Sally did not see the baby-elephant, but that of a pig.' 
The combination of CON and R2 is a common source of word formation. Often the target is a (pro-)adverbial. As can be seen in (87) the agreement prefix on the connective relator is often that of the locative agreement pattern XVII (ku-).

(86) Mongo (Hulstaert 1966: 236)

$$
\begin{aligned}
& \text { ǒ-a = nsómí } \\
& \text { I-CON=[9]first_born }
\end{aligned}
$$

'firstborn'

(87) Makwe (Devos 2008: 135)
a. kwa cáani 'why?'
b. kwa úyóovi 'therefore'
c. kwa kílá siíku 'everyday'
d. kwa yaámbi 'as for now'
e. kwa síku jámbééle 'in the future'

The Ruwund interrogative pro-adverbial meaning 'what for' consists of a pronominalised connective relator followed by the interrogative 'why'. The relator agrees with the noun for the entity the purpose of which is questioned. 
(88) Ruwund (Nash 1992: 372)
a. lêt ci-twààmu
bring 7-chair
'Bring a chair!'
b. c-áa-k
VII-CON-why
'what for?'

Certain patterns of lexicalisation of CON R2 are so recurrent that the connective relator involved in them can be analysed as a derivational morpheme. In Zulu, patronyms are regularly derived from personal names by means of the connective relator $\mathrm{ka}$, which does not contain an overt agreement marker in agreement patterns I, III, IV, VI and IX (89).

(89) Zulu (Doke 1997: 119)
a. uNtengo kaJojo 'Tengo, son of Jojo'
b. uMpande kaSenzangakhona 'Mpande, son of Senzangakona'
c. wena kaJojo! 'Thou, son of Jojo!' 
In Langi, many nominals consist of a connective relator of agreement pattern VII apparently agreeing with the class 7 word ki-ntu 'thing' - and a full noun, e.g., tfaamutonds 'breakfast' ( < mutonds 'morning', cl.9) (Dunham 2005: 114).

Pronominalised connective relators, followed or not by a fixed $\mathrm{R} 2$, are a very common source of closed class elements such as prepositions, subordinators and adverbs. ${ }^{13}$ In some cases the distinction between derivational morpheme and preposition is not self evident, for instance where a connective relator of a locative agreement pattern preceding a personal noun expresses the notion of 'at somebody's place' (90-91). In many languages locative nouns cannot be directly derived from personal proper names by means of a locative class prefix.

(90) Ha (Tanzania; Harjula 2004: 65)

a. Ng-end-é $\quad \mathrm{kw}$-a = Máriámu

1sG-go-SBJV 17-CON=Mariamu

'Let me go to Mariamu'

b. mw-a=Chíisohoye

18-CON=Chiisohoye

'at Chisohoye's'

\footnotetext{
${ }^{13}$ It would be interesting to know whether this evolution is sometimes accompanied by antimorphologisation, i.e. an evolution towards a lower degree of morphological bonding (see Idiatov 2008).
} 
(91) Songye (Stappers 1964: 56)

kwamúkají 'at the woman's place’

kwămfumú 'at the chief's'

In Ruwund the connective relator of agreement pattern V (dà) developed into the preposition 'via' or 'through' and that of agreement pattern XI (rà) into a preposition meaning 'by (means of transportation)' (92). Something similar is found in Mongo, where 'via' is expressed by the connective relator of agreement pattern I (93). Another recurrent preposition that develops from connective relators is 'for' (94-95).

(92) Ruwund (Nash 1992: 382)

a. dà masuku

'through the bush'

b. dà kûns

'by side path'

c. rà nking

'by bike'

d. rà pânsh

'on foot' (pânsh 'on the ground') 
(93) Mongo (Hulstaert 1966: 239)

to-ó-y-é ǒa ntando

1PL-HAB-come-FV via [9]river

'We come via the river.'

(94) Ha (Harjula 2004: 65)

b-a-rim-a kwa Tunguhore

II-PRS-cultivate-FV for Tunguhore

'They cultivate for Tunguhore' ( $k w a<k u-a$ XVII-CON)

(95) Lwalwa (DRC, Ndembe-Nsasi 1972: 120)

bwáamí

'for me' $(<b u-a=m i$; XIV-CON=1SG.PPR $)$

When R2 is a non-finite verb form, a pronominalised connective relator functions as a subordinator introducing an adverbial clause.

(96) Makwe (Devos 2008: 135)

ńníiída kw-a=ku-lífúunda ki-máakwe

I.came $\quad \mathrm{XV}-\mathrm{CON}=15$-study $\quad 7-\mathrm{Makwe}$ 
'I came to study Makwe'

(97) Kete (Kamba-Muzenga 1980: 112)

bw-a: = kú-cwu-mon

XIV-CON=15-1PL-see

'in order to see us'

In the Lwalwa example in (98), bwáamí (see ex. 95) introduces a purpose clause. This is another example of agreement in an unusual place: a subordinator indexing the object of the adverbial clause it introduces.

(98) Lwalwa (Ndembe-Nsasi 1972)

bwáamí kumóno 'in order to see me’

7. Departures from the canonical arrangement of constituents

\subsection{R1, CON and $R 2$ are not adjacent}

Canonically R1, the connective relator and R2 are adjacent. In a common departure from the canon, CON R2 is separated from R1 by other modifiers of R1 (99). Example (99) also illustrates that CON R2 can be preceded by modifiers that have scope over it. 
(99) Kagulu (Petzell 2008: 196)

i-mu-ana yu-ya u-a =i-chike

AU-1-child I-DEM I-CON=AU-feminine

'that young girl'

\subsection{The order of elements is not R1 CON R2}

The connective relator is placed iconically between R1 and R2 in the canonical construction. Departures from the canon on this dimension are rarely mentioned in the literature. One partial departure can be found in Mongo in the case of coordinated R1s, where CON R2 can be placed either after the second R1 (100a), or, non-canonically, in between the coordinated R1s (100b).

(100) Mongo (Hulstaert 1966)

a. bo-ngángo l' a-kulá w-ă mbengi

3-bow and 6-arrow III-CON 9.hunter

b. bo-ngángo w-ă mbengi l' a-kulá

3-bow III-CON 9.hunter and 6-arrow

'the bow and arrows of the hunter'

Also in Mongo, CON R2 can be placed in front of R1 in order to express contrastive focus. 
(101) Mongo (Hulstaert 1966: 284)

y-ă = fâfá nyàmà $\quad$ y-òl-òtsw-à nd' é-lóngó

$\mathrm{X}-\mathrm{CON}=$ my_father $[10]$ animals $\mathrm{X}-\mathrm{PST}-\mathrm{enter}-\mathrm{FV}$ in 7-barn

'My father's animals have entered the barn (in contrast to the others).'

\section{Conclusions}

The main typological characteristics of a typical connective construction, the construction used to express adnominal possession in the Bantu languages, are well known and can be summarised as follows:

(102) a. two nominal constituents are in a relation of dependency

b. the dependent nominal follows the head nominal

c. the dependent nominal is marked by a dedicated connective relator, which agrees with the head nominal

d. the connective construction is not dedicated to the expression of possession, nor of any other relation

Even the minimal characteristics in (102a-c) prove to be too strong as necessary definitional criteria for the connective construction. They do not apply to several construction types, illustrated in this paper, that one would wish to classify as connective constructions on the basis of their family resemblance with typical instances of the construction. Thus, we saw 
several construction types in which a connective marker links a head nominal to a clearly non-nominal dependent and there is not always a clear cut-off point between a clearly nominal and a clearly non-nominal dependent. For instance, as we saw in section 3.2, nominalised verb forms like infinitives that are marked by a connective relator, can be gradually elaborated with more and more verbal features, which creates a continuum of construction types between a typical connective construction on the one hand and a typical relative clause construction on the other, with no non-arbitrary cut-off point in between them.

The aim of this paper was to provide an overview of the formal and functional variation in construction types that show a family resemblance to typical connective constructions. In order to do this, I defined a canonical type and then described the formal variation found among connective constructions in terms of departures from the canon along several dimensions. The canonical type reflects the prototypical connective construction in the mind of the Bantuist. No claims are made regarding the higher frequency or the diachronic primacy of the canonical type as opposed to other types. That being said, the canonical construction is the only one that was found in every description that I consulted, at least if we ignore the form of the connective relator in the definition of the canonical type. This may be due to the fact that many grammarians do not go beyond discussing the construction type that they perceive as prototypical. It may also mean that the canonical type is diachronically primary (with some uncertainty regarding the form of the connective relator in the protolanguage). The variation described in this paper could then be explained in terms of extensions from the original use of the connective relator. With respect to departures from the canonical second relatum (R2) it should be pointed out that no Bantu language 'extended' the use of the connective relator to become a generalised marker of adnominal modification. 
At several points in the discussion of departures from the canon, it became clear that a canonical approach is useful for the description of parts of speech categories in individual languages too. In section 3.1, for instance, I referred to canonical Makwe adjectives in order to distinguish them from some of the non canonical adjective types that can occur in R2 position, which can equally well be characterised as non-canonical nouns. Thus, kibúúli 'silent' has the distributional potential of an adjective, but the morphological characteristics of a noun.

Many of the departures from the canonical connective construction appear to be crosslinguistically rare and theoretically interesting. Examples are dependency reversal (section 5.1), nominal tense (section 4.4) and the classifier-like constructions in section 5.2.1. A connective origin explains a number of unusual agreement phenomena, like the fact that Bantu possessive pronouns have two agreement controllers, or some instances of agreement in unusual places, e.g. on the non selective interrogative 'what for' in Ruwund. Also, we have seen hints of the role of the connective relator in coding information structure within the nominal constituent. Where its presence is optional, the connective relator appears to foreground its second relatum, as with the Lingala adjectives in section 3.1 and the examples of optional connective relators in section 5.2. I was often unable to go beyond enumerating these typologically interesting phenomena, since, due to the scarcity of detailed grammatical descriptions of Bantu languages, my knowledge of them is based on a small number of examples and their translation equivalent. For the same reason I do not know how recurrent the different departures from the canonical connective construction are throughout the Bantu family. An overwhelming majority of the departures from the canon can be found in 
Hulstaert's detailed description of Mongo, a large and rather diverse dialect cluster, which Gustaaf Hulstaert tried to unify in an effort of standardisation. The availability of more thorough grammatical descriptions of other Bantu languages is likely to make Mongo seem less exceptionally rich. The canonical typology put forward here could serve as a questionnaire for future descriptive work.

\section{References}

Ambouroue, Odette. 2007. Eléments de description de l'orungu, langue bantu du Gabon (B11b). PhD thesis. Université Libre de Bruxelles. (available at http://theses.ulb.ac.be/ETD-db/collection/available/ULBetd-07162007152714/unrestricted/TheseAmbouroue.pdf)

Asangama, Natisa. 1983. Le budu: langue bantu du nord-est du Zaïre. Esquisse phonologique et grammaticale. $\mathrm{PhD}$ thesis. INALCO/Paris III.

Baka, Jean. 2000. L'adjectif en bantu. PhD thesis. ULB.

Bokamba, Georges D. 1971. Specificity and definiteness in Dzamba. Studies in African Linguistics 2-3, 217-237.

Bosch, Sonja E. 1997. Possible origins of the possessive particle -ka- in Zulu. South African Journal of African Languages. 17 (1), 1-5.

Bouka, Léonce Yembi. 1994. L'accord des adjectifs du protobantou en zone H. Africana Linguistica 11, 13-18.

Bynon-Polak, Louise. 1965. L'expression des ordinaux dans les langues bantoues. Africana Linguistica 2, 127-160. 
Corbett, Greville G. 2007. Canonical typology, suppletion and possible words. Language 38 (1), 8-42.

Creissels, Denis. 1993. Description du tswana. Unpublished manuscript. Grenoble: Université Stendhal.

Devos, Maud. 2008. A Grammar of Makwe. München: LINCOM.

Dik, Simon. 1989. The Theory of Functional Grammar. Dordrecht: Foris.

Dunham, Margaret. 2005. Elements de description du langi, langue bantu F33. Leuven/Paris: Peeters.

Fivaz, Derek. 1986. A Reference Grammar of Oshindonga. Windhoek: Bureau for Research, University of Namibia.

Guarisma, Gladys. 2000. Complexité morphologique - simplicité syntaxique. Le cas du Bafia, langue bantoue périphérique (A50) du Cameroun. Leuven/Paris: Peeters.

Greenberg, Joseph H. 1978. How does a language acquire gender markers? In Universals of Human Language, III: Word Structure, Joseph H. Greenberg, Charles A. Ferguson and Edith A. Moravcsik (eds.), 47-82. Stanford: Stanford University Press.

Güldemann, Tom. 1999. The ka-possessive in southern Nguni. Journal of African Languages and Linguistics 20, 157-184.

Güldemann, Tom. 2008. The Macro-Sudan belt: towards identifying a linguistic area in northern sub-Saharan Africa. In A Linguistic Geography of Africa, Bernd Heine and Derek Nurse (eds.), 151-185. Cambridge: Cambridge University Press.

Hadermann, Pascale. 1994. Aspects morphologiques et syntaxiques de l'infinitif dans les langues bantoues. Africana Linguistica. 11, 79-91. 
Harjula, Lotta. 2004. The Ha Language of Tanzania. Grammar, Texts and Vocabulary. Köln: Rüdiger Köppe Verlag.

Hawkinson, Annie K. 1979. Homonymy versus unity of form: the particle -a in Swahili. Studies in African Linguistics 10 (1), 81-109.

Henson, Bonnie. 2007. The Phonology and Morphosyntax of Kol. PhD dissertation. University of California, Berkeley.

Hulstaert, Gustaaf. 1946. Connectieve bijzinnen in Lomongo. Aequatoria. 5, 135-137.

Hulstaert, Gustaaf. 1957. Dictionnaire lomóngo-français. Tervuren: Royal Museum for the Belgian Congo.

Hulstaert, Gustaaf. 1965. Grammaire du lomóngo. Deuxième partie. Morphologie. Tervuren: Royal Museum for Central Africa.

Hulstaert, Gustaaf. 1966. Grammaire du lomóngo. Troisième partie. Syntaxe. Tervuren: Royal Museum for Central Africa.

Hulstaert, Gustaaf. 1993. Connectif et possessif dans les dialectes mongo. Annales Aequatoria $14,334-344$.

Hyman, Larry M. 2003. Basaá (A43). In The Bantu Languages, Derek Nurse and Gérard Philippson (eds.), 257-282. London: Routledge.

Idiatov, Dmitry. 2008. Antigrammaticalisation, antimorphologization and the case of Tura. In Theoretical and Empirical Issues in Grammaticalisation, Elena Seoane, María José LópezCouso and Teresa Fanego (eds.), 151-169. Amsterdam/Philadelphia: John Benjamins. Kagaya, Ryohei. 1992. A Classified Vocabulary of the Bakueri Language. Tokyo: ILCAA. 
Kamba Muzenga, Jean-Georges. 1980. Esquisse de grammaire kete. Tervuren: Royal Museum for Central Africa.

Lumwamu, François. 1973. Essai de morphosyntaxe systématique des parlers koongo. Paris: Klincksieck.

Maganga, Clement and Thilo C. Schadeberg. 1992. Kinyamwezi: grammar, texts, vocabulary. Köln: Rüdiger Köppe Verlag.

Maho, Jouni Filip. 1999. A Comparative Study of Bantu Noun Classes. Orientalia et Africana gothoburgensia, n 13. Göteborg: Acta Universitatis Gothoburgensis.

Malchukov, Andrej L. 2000. Dependency Reversal in Noun-Attributive Constructions: towards a typology. München: LINCOM.

Meeuwis, Michael. 1998. Lingala. München: LINCOM.

Mufwene, Salikoko S. 2003. Contact languages in the Bantu area. In The Bantu Languages, Derek Nurse and Gérard Philippson (eds.), 195-208. London: Routledge.

Möhlig, Wilhelm, Lutz Marten and Jekura Kavari. 2002. A Grammatical Sketch of Herero (Otjiherero). Köln: Rüdiger Köppe Verlag.

Nash, Jay Arthur. 1992. Aspects of Ruwund grammar. PhD thesis. University of Illinois at Urbana-Champaign.

Ndembe-Nsasi, Damase. 1972. Esquisse phonologique et morphologique de la langue lwalwa. Mémoire de licence. Université Nationale du Zaïre, Lubumbashi.

Nordlinger, Rachel and Luisa Sadler. 2004. Nominal tense in crosslinguistic perspective. Language 80 (4): 776-806.

Nzang Bie, Yolande. 1995. Le connectif dans les langues bantu: analyses synchroniques et perspectives diachroniques. $\mathrm{PhD}$ thesis. Université Libre de Bruxelles. 
Petzell, Malin. 2008. The Kagulu Language of Tanzania. Grammar, texts and vocabulary. Köln: Rüdiger Köppe Verlag.

Perez, Carolyn Harford. 1985. Aspects of Complementation in three Bantu Languages. PhD thesis. University of Wisconsin-Madison.

Rijkhoff, Jan. 2002. The Noun Phrase. Oxford: Oxford University Press.

Rodegem, Firmin M. 1970. Syntagmes complétifs spéciaux en rundi. Africana Linguistica 4, 181-207.

Ross, Malcolm. 1998. Possessive-like attribute constructions in the Oceanic languages of northwest Melanesia. Oceanic Linguistics 37 (2), 234-276.

Rurangwa, Innocent Moïse. 1982. Elements de description du ngungwel, langue bantoue du congo. Masters thesis. Université Libre de Bruxelles.

Stappers, Leo c.i.c.m. 1964. Morfologie van het Songye. Tervuren: Royal Museum for Central Africa.

Tshibasu Balekelay. 1985. Les formes pronominales en bemba (approche structurale). Masters thesis. Lubumbashi: Institut Supérieur Pédagogique de Lubumbashi.

Tucker, Archibald N. 1960. Notes on Konzo. African Language Studies 1:16-41.

Van de Velde, Mark L.O. 2006. Multifunctional agreement patterns in Bantu and the possibility of genderless nouns. Linguistic Typology 10 (2), 183-221.

Van de Velde, Mark L.O. 2008. A Grammar of Eton. Berlin: Mouton de Gruyter.

Van de Velde, Mark L.O. and Odette Ambouroue. 2011. The grammar of Orungu proper names. Journal of African Languages and Linguistics 32, 113-141.

Van Langendonck, Willy. 2007. Theory and Typology of Proper Names. Berlin: Mouton de Gruyter. 
Van Eeden, B.I.C. 1956. Zoeloe-grammatika. Stellenbosch: Universiteitsuitgewers en boekhandelaars.

Welmers, William Everrett. 1963. Associative $a$ and $k a$ in Niger-Congo. Language, 39 (3), $432-447$. 